\title{
Childhood Brain Stem Astrocytoma
}

National Cancer Institute

\section{Source}

National Cancer Institute. Childhood Brain Stem Astrocytoma. NCI Thesaurus. Code C6216.

An astrocytoma that arises from the brain stem and occurs during childhood. 